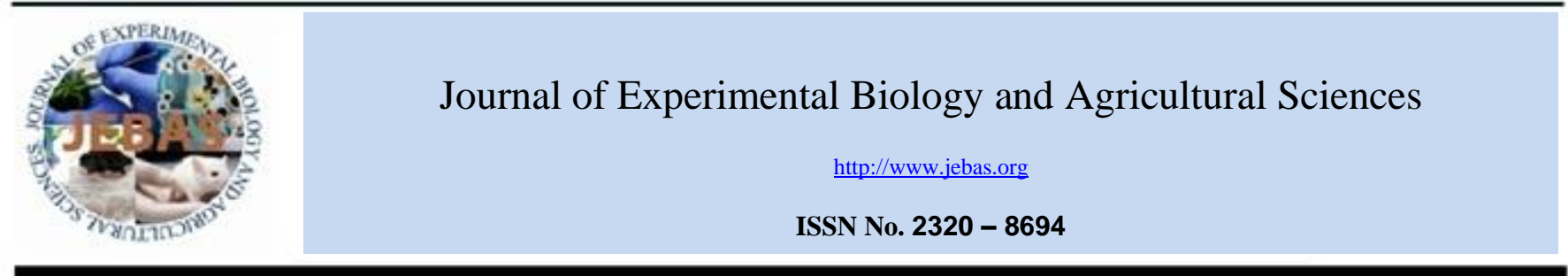

\title{
THERAPEUTIC APPLICATIONS OF Spirulina AGAINST HUMAN PATHOGENIC VIRUSES
}

\section{Sharolynne Xiao Tong Liang ${ }^{1}$, Ling Shing Wong ${ }^{2}$, Anto Cordelia Tanislaus Antony Dhanapal $^{3}$, Prakash Balu ${ }^{4}$, Sinouvassane Djearamane ${ }^{1^{*}}$}

\author{
${ }^{1}$ Department of Biomedical Science, Faculty of Science, Universiti Tunku Abdul Rahman, Kampar, 31900 Malaysia \\ ${ }^{2}$ Life Science Division, Faculty of Health and Life Sciences, INTI International University, Nilai, 71800 Malaysia \\ ${ }^{3}$ Department of Chemical Science, Faculty of Science, Universiti Tunku Abdul Rahman, Kampar, 31900 Malaysia \\ ${ }^{4}$ Department of Biotechnology, School of Life Sciences, Vels Institute of Science, Technology and Advanced Studies (VISTAS), Chennai, Tamil Nadu, 600117, India \\ Received - July 18, 2020; Revision - September 17, 2020; Accepted - January 03, 2021 \\ Available Online - March 25, 2021
}

DOI: http://dx.doi.org/10.18006/2021.9(Spl-1-GCSGD_2020).S38.S42

\section{KEYWORDS \\ Spirulina \\ Cyanobacteria \\ Antiviral \\ Immunostimulant}

\section{* Corresponding author}

E-mail: sinouvassane@utar.edu.my/biochsinouvas07@gmail.com (Sinouvassane Djearamane)

Peer review under responsibility of Journal of Experimental Biology and Agricultural Sciences.

Production and Hosting by Horizon Publisher India [HPI] (http://www.horizonpublisherindia.in/).

All rights reserved.

\begin{abstract}
Viruses can spread worldwide and the early detection of emerging infectious diseases and outbreaks in humans and animals is important for effective surveillance and prevention. Viruses such as human immunodeficiency virus (HIV), swine flu, and influenza virus are some of the viruses that spread diseases worldwide. However, the non-availability of effective antiviral drugs and the drug-resistance among the virus and host have become the major problems in controlling viral infections. The natural products from microalgae can be an alternative therapeutic agent to control viral infections in humans. Spirulina is a well-known cyanobacterium that has been consumed by humans as a food supplement for more than centuries without side-effects. Spirulina possesses high nutritional values and provides numerous health benefits to the consumers. Spirulina can be an alternative natural therapeutic agent for numerous virus infections as it contains several bioactive compounds with proven antiviral effect on enveloped viruses (Herpes simplex virus, measles virus, mumps virus) and non-enveloped viruses (astrovirus, rotavirus) by preventing the spread of the virus in the host cells. Spirulina also serves as a natural supplement that strengthens the immune system. This review focuses on the antiviral properties and immunostimulant effects of Spirulina as a potential therapeutic supplement on human health.
\end{abstract}

All the articles published by Journal of Experimental Biology and Agricultural Sciences are licensed under a Creative Commons Attribution-NonCommercial 4.0 International License Based on a work at www.jebas.org.

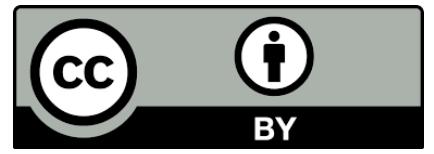




\section{Introduction}

Viruses are cellular and obligate intracellular parasites that can cause viral infection in host cells and are harmful to all living organisms including humans, animals, and plants (Koonin et al., 2006). Viruses can spread disease worldwide through many factors such as contaminated water and food, environmental factors such as air and soil, person to person, insects, and vectors. Early detection of emerging infectious diseases and outbreaks in humans and animals is important for effective surveillance and prevention (Ramakrishnan, 2013). There are around 219 human infecting virus species that are known, and the first human infecting virus discovered was yellow fever in 1901 (Woolhouse et al., 2012). Carcinogenic viruses and other disease causative viruses including Chikungunya virus, dengue virus, acute respiratory syndrome coronavirus (SARS-CoV), human immunodeficiency virus (HIV), influenza virus, Herpes simplex virus (HSV), severe swine flu, human papilloma virus (HPV), and human T-lymphotropic viruses (HTLV-I, HTLV-II) are the most important viruses spreading diseases worldwide (Ramakrishnan, 2013). Drug-resistance of the virus and the host have made the treatment of viral infection using chemical drugs difficult. One alternative way to overcome the drug-resistant issue is to substitute chemical drugs with natural biological compounds (Ramakrishnan, 2013). The natural products from microalgae can be an alternative therapeutic agent to effectively control the viral infections in humans.

Cyanobacteria are one of the oldest photosynthetic organisms that are found in different aquatic environments (Nuhu, 2013). Spirulina is known to be a "superfood", named by the World Health Organization (WHO), and is recommended to be a compact food during space travel for astronauts of National Aeronautics and Space Administration (NASA) (Koyande et al., 2019). Spirulina has been consumed for more than centuries as food and supplements for humans, traditionally by the native population at Lake Chad area and the Aztec population of Mexico (Djeramane et al., 2018; Koyande et al., 2019). The species of Spirulina includes S. platensis, S. laxissima, S. subsalsa, S. fusiformis, S. maxima, and S. lonar. However, between all the species, S. platensis and $S$. maxima are more popular and mostly used for nutritional and therapeutic purposes (Kameshwari et al., 2020).

Spirulina contains a high level of nutrients such as protein, lipid, carbohydrate, amino acids, vitamins, minerals, pigments, and others (Khan et al., 2005). Generally, Spirulina contains 55-70\% protein, $15-25 \%$ carbohydrate, 6-13\% nucleic acids, 5-6\% lipid, and 2.2-4.8\% minerals (Reboleira et al., 2019). Vitamins such as $\mathrm{B}_{1}, \mathrm{~B}_{2}, \mathrm{~B}_{3}$ and $\mathrm{B}_{12}$, photosynthetic pigments, and minerals like calcium, copper, iron, magnesium, phosphate, sodium, and zinc are rich in Spirulina species (Wan et al., 2016). Spirulina is a natural immunity booster, detoxifier, appetite suppressant, and antioxidant that provide a wide range of benefits upon consumption (Singh et al., 2020). The antibacterial, anticancer, antiviral, and anti-parasitic properties of Spirulina are being widely studied by researchers (Martínez-Galero et al., 2016; Fayyad et al., 2019; Abd El-Baky \& El-Baroty, 2020; Joseph et al., 2020). Besides, Spirulina is also being used in clinical studies due to its high functional and nutritional properties in treating a range of pathogenic conditions such as allergies, inflammatory diseases, hypercholesterolemia, heavy-metal poisoning, cardiovascular diseases and radiation poisoning (Reboleira et al., 2019; Kameshwari et al., 2020).

\section{Antiviral properties}

The National Cancer Institute (NCI) research group screened the lipophilic and hydrophilic extracts obtained from 300 species of cyanobacteria to examine their antiviral properties and reported that about $10 \%$ of the cultures were shown to reduce the cytopathic effects induced by a viral infection (Patterson et al., 1993). The bioactive compounds of microalgae such as nostoflan from Nostoc flagelliforme and fucoidan from the sporophyll of Undaria pinnatifida exhibit an antiviral effect on several enveloped viruses (Hayashi, 2008) and, ichthyopeptins A and B, the two novel depsipeptides from Microcystis ichthyoblabe inhibit the viral protein of influenza A virus (Zainuddin et al., 2007). Spirulina naturally can inhibit the activity of viruses as it has all the biomolecules which can build a strong immune system that can scavenge free radicals (Ali \& Saleh, 2012). The extracts isolated from S. platensis and S. maxima were reported to possess antiviral properties (Hernandez-corona et al., 2002; El-Baz et al., 2013; Kameshwari et al., 2020). The antiviral activity of Spirulina mostly depends on the richness of proteins (phycocyanin), sulphated polysaccharide fragments, fatty acids (sulpholipids), minerals, and some other constituents (Nuhu, 2013; Kameshwari et al., 2020).

The antiviral effect of $S$. platensis against enveloped viruses such as human cytomegalovirus (HCMV), HSV-1, measles virus, mumps virus, HIV-1, and influenza virus is mainly contributed by the acidic or sulphated polysaccharides, calcium spirulan (Ca-SP) isolated from hot water extract of $S$. platensis that acts through inhibiting the replication of the viruses (Nuhu, 2013; Ramakrishnan, 2013). The aqueous extract of S. platensis is found to significantly inhibit the in vitro replication of HIV-1in human Tcell lines, Langerhans cells, and peripheral blood mononuclear cells (PBMCs) (Hoseini et al., 2013; Ramakrishnan, 2013), with up to $50 \%$ viral reduction on PBMCs using extract concentration between 0.3 to $1.2 \mu \mathrm{g} / \mathrm{mL}$ (Ayehunie et al., 1998). Further, the water extract of $S$. platensis inhibited HSV-1 replication in HeLa cells by interfering with the entry of the virus into the host cells, although the extract is not virucidal (Hayashi et al., 1993). Besides the enveloped viruses, S. platensis also demonstrated the antiviral effects on non-enveloped RNA and DNA enteric viruses. The 
ethanol extract of $S$. platensis caused a reduction of $76.7 \%$ on astrovirus type $1,66.7 \%$ on Coxsackievirus, $53.3 \%$ on adenovirus type $7,56.7 \%$ on rotavirus Wa strain, and $50 \%$ on adenovirus type 40. The virucidal effect of $S$. platensis extract using ethanol showed a higher reduction on RNA viruses than DNA viruses (ElBaz et al., 2013). Allophycocyanin isolated from S. platensis is proven to inhibit $50 \%$ of viral-induced cytopathic effect in African green monkey kidney cells and human rhabdomyosarcoma cells at concentrations of $0.056-0.101 \mu \mathrm{M}$ on enterovirus 71 by interfering with viral RNA synthesis in infected cells. The treatment of allophycocyanin to the host cells before viral infection showed higher antiviral activity than treatment after infection (Shih et al., 2003). Other than S. platensis, Hernandez-corona et al., (2002) reported that methanol-water (3:1) extract of $S$. maxima exhibited the highest antiviral activity on HSV-2 among hexane, chloroform, methanol, and hot water extracts. S. maxima extract prepared using hot water showed less than $20 \%$ inhibition on adenovirus type 3 with $\mathrm{IC}_{50} 5.2 \mathrm{mg} / \mathrm{mL}$ and no inhibition was observed at concentrations below $2 \mathrm{mg} / \mathrm{mL}$ (Hernandez-corona et al., 2002; Rahman et al., 2006).
Abd El-Baky \& El-Baroty (2020), reported that L-asparaginase (LAsnA) purified from S. maxima showed a dose-dependent antiviral effect on Coxsackie B3 (CSB3) virus where $17.03 \mu \mathrm{g} / \mathrm{mL}$ of L-AsnA inhibited 50\% of CSB3 virus and suggested that inhibition of viral replication cycle might be the mechanism behind the antiviral effect. Similarly, Sharaf et al. (2010) reported that the crude extracts of $S$. fusiformis caused inhibition of HSV replication in host cells on both pre and post-infection stages.

Further, Spirulina contains about 2-5\% of sulpholipids, which are effective against the enzymatic activity of HIV-1 reverse transcriptase (RT). A minimum concentration of $24 \mathrm{nM}$ of sulpholipids can exhibit 50\% inhibition by selectively acting on DNA polymerase of HIV-1 RT (Hoseini et al., 2013). A study on carbohydrate-binding agents that demonstrated the inhibition of HIV-1 and other enveloped viral particles suggested that cyanovirin-N (CV-N) isolated from Spirulina has the potential as an anti-HIV therapeutic agent in the future (Balzarini, 2007). Table 1 and 2 shows the antiviral properties of $S$. platensis and $S$. maxima, respectively.

Table 1 Antiviral properties of S. platensis

\begin{tabular}{|c|c|c|c|}
\hline Compound name & Virus & Antiviral property & Authors \\
\hline $\begin{array}{l}\text { Ca-SP from hot water } \\
\text { extract }\end{array}$ & $\begin{array}{l}\text { HSV-1, HCMV, Measles, } \\
\text { Mumps, HIV-1, Influenza }\end{array}$ & Inhibit viral replication in vitro. & $\begin{array}{l}\text { Nuhu, 2013; Ramakrishnan, } \\
2013\end{array}$ \\
\hline Ethanol extract & $\begin{array}{l}\text { Astrovirus type } 1 \text {, } \\
\text { Coxsackievirus, Rotavirus Wa } \\
\text { strain, Adenovirus type 7, } \\
\text { Adenovirus type 40 }\end{array}$ & $\begin{array}{l}\text { Higher virucidal effect on RNA viruses than } \\
\text { DNA viruses (in vitro). }\end{array}$ & El-Baz et al., 2013 \\
\hline Aqueous extract & HIV-1 & $\begin{array}{l}\text { Inhibit viral replication in PBMCs, human } \\
\text { T-cell lines, and Langerhans cells (in vitro). }\end{array}$ & Ayehunie et al., 1998 \\
\hline Water extract & HSV-1 & $\begin{array}{l}\text { Inhibit viral replication and prolong the } \\
\text { survival time of virally infected hamster. }\end{array}$ & Hayashi et al., 1993 \\
\hline Allophycocyanin & Enterovirus 71 & $\begin{array}{l}\text { Delay viral RNA synthesis and activate } \\
\text { apoptosis (in vitro). }\end{array}$ & Shih et al., 2003 \\
\hline
\end{tabular}

Table 2 Antiviral properties of S. maxima

\begin{tabular}{|l|l|l|l|}
\hline \multicolumn{2}{|c|}{ Compound name } & \multicolumn{2}{c|}{ Antiviral property } \\
\hline Hot water extract & HSV-1, HSV-2 & $\begin{array}{l}\text { Inhibit viral infection in Vero cells by interfering viral } \\
\text { infectious cycle, adsorption and penetration. }\end{array}$ & $\begin{array}{l}\text { Hernandez- } \\
\text { corona et al., } \\
2002\end{array}$ \\
\hline $\begin{array}{l}\text { Methanol-water } \\
\text { extract }\end{array}$ & HSV-2 & $\begin{array}{l}\text { Block viral infectious cycle at adsorption and } \\
\text { penetration stages. }\end{array}$ & $\begin{array}{l}\text { Hernandez- } \\
\text { corona et al., } \\
2002\end{array}$ \\
\hline L-AsnA & CSB3 virus & Inhibit viral replication cycle. & $\begin{array}{l}\text { Abd El-Baky \& } \\
\text { El-Baroty, 2020 }\end{array}$ \\
\hline
\end{tabular}

Journal of Experimental Biology and Agricultural Sciences http://www.jebas.org 


\section{Immunostimulant effects}

Numerous Spirulina supplements can be found in the market nowadays as they contain high nutritional values and are reported to exhibit immune-stimulating properties (Jung et al., 2019; Singh et al., 2020). Spirulina was found to activate macrophages, natural killer (NK) cells, T-cells, and B-cells (Nuhu, 2013; Singh et al., 2020), and further enhance immunity by increasing the production of antibodies, interferon-gamma (IFN- $\gamma$ ), and cytokines (Nuhu, 2013; Banakar et al., 2020).

Natural substances isolated from Spirulina are reported to be effective inhibitors against enveloped and non-enveloped viruses by interfering or blocking the adsorption and penetration of virus, and also inhibit viral replication in the host cells (Singh et al., 2020). Populations in Japan, Korea, and Africans at Chad area that consume Spirulina daily with an average of 3-13 g, reported to have lower cases of HIV and acquired immune deficiency syndrome (AIDS) as compared to the other populations that do not take Spirulina diet (Teas et al., 2004).

The HIV/AIDS prevalence of algae-consuming populations in Eastern Asia (Japan and Korea) is about 1/10,000 adults, as compared to Africa which has a high prevalence of $1 / 10$ adults (Teas et al., 2004).

\section{Conclusion and recommendation for future research}

It is evident from the literature that Spirulina has high nutritional values and provides a wide range of nutritional and health benefits. Numerous research studies have proven that the extracts from $S$. platensis and S. maxima can inhibit the spreading of enveloped and non-enveloped viruses in host cells. Besides, the immunestimulating effects of Spirulina products on human health offer Spirulina to be a potential therapeutic supplement. Further research is needed to determine its' usefulness against different viruses and unlock its potential. The multifunctional role of Spirulina makes it as an ideal natural drug with immense prophylactic and therapeutic properties.

\section{References}

Abd El-Baky HH, El-Baroty GS (2020) Spirulina maxima Lasparaginase: Immobilization, Antiviral and Antiproliferation Activities. Recent Patents on Biotechnology 14: 154-163.

Ali SK, Saleh AM (2012) Spirulina-An Overview. International Journal of Pharmacy and Pharmaceutical Sciences 4: 9-15.

Ayehunie S, Belay A, Baba TW, Ruprecht RM (1998) Inhibition of HIV-1 Replication by an Aqueous Extract of Spirulina platensis (Arthrospira platensis): Journal of Acquired Immune Deficiency Syndromes and Human Retrovirology 18: 7-12.
Balzarini J (2007) Carbohydrate-Binding Agents: A Potential Future Cornerstone for the Chemotherapy of Enveloped Viruses? Antiviral Chemistry and Chemotherapy 18: 1-11.

Banakar V, Alam Q, Rajendra S, Pandit A, Cladious A, Gnanaprakash K (2020) Spirulina, The Boon of Nature. International Journal of Research in Pharmaceutical Sciences 11: $57-62$.

Djearamane S, Lim YM, Wong LS, Lee PF (2018) Cytotoxic effects of zinc oxide nanoparticles on cyanobacterium Spirulina (Arthrospira) platensis. PeerJ 6:e4682

El-Baz FK, El-Senousy WM, El-Sayed AB, Kamel MM (2013.) In vitro antiviral and antimicrobial activities of Spirulina platensis extract. Journal of Applied Pharmaceutical Science 3: 52-56.

Fayyad RJ, Mohammed Ali AN, Dwaish AS, Al-Abboodi AKA (2019) Anticancer Activity of Spirulina platensis Methanolic Extracts Against L20B and MCF7 Human Cancer Cell Lines. Plant Archives 19: 1419-1426.

Hayashi K, Hayashi T, Morita N, Kojima I (1993) An extract from Spirulina platensis is a selective inhibitor of herpes simplex virus type 1 penetration into HeLa cells. Phytotherapy Research 7: 7680.

Hayashi T (2008) Studies on Evaluation of Natural Products for Antiviral Effects and Their Applications. Yakugaku Zasshi 128: 61-79.

Hernandez-corona A, Nieves I, Meckes M, Chamorro G, Barron B (2002) Antiviral activity of Spirulina maxima against herpes simplex virus type 2. Antiviral Research 56: 279-285.

Hoseini SM, Khosravi-Darani K, Mozafari MR (2013) Nutritional and Medical Applications of Spirulina Microalgae. Mini-Reviews in Medical Chemistry 13: 1231-1237.

JosephJ, Karthika T, Ajay A, Das VRA, Raj VS (2020) Green tea and Spirulina extracts inhibit SARS, MERS, and SARS-2 spike pseudotyped virus entry in vitro (preprint). Microbiology.

Jung F, Krüger-Genge A, Waldeck P, Küpper JH (2019) Spirulina platensis, a super food? Journal of Cellular Biotechnology 5: 4354.

Kameshwari V, Selvaraj S, Sundaramoorthy S (2020) Single Cell Protein Spirulina - A Nutrient Treasure - Review. Research Journal of Pharmacology and Pharmacodynamics 12: 1-7.

Khan Z, Bhadouria P, Bisen P (2005) Nutritional and Therapeutic Potential of Spirulina. Current Pharmaceutical Biotechnology 6: 373-379. 
Koonin EV, Senkevich TG, Dolja VV (2006) The ancient Virus World and evolution of cells. Biology Direct 1: 29.

Koyande AK, Chew KW, Rambabu K, Tao Y, Chu DT, Show PL (2019) Microalgae: A potential alternative to health supplementation for humans. Food Science and Human Wellness 8: $16-24$.

Martínez-Galero E, Pérez-Pastén R, Perez-Juarez A, FabilaCastillo L, Gutiérrez-Salmeán G, Chamorro G (2016) Preclinical antitoxic properties of Spirulina (Arthrospira). Pharmaceutical Biology 54: 1345-1353.

Nuhu AA (2013) Spirulina (Arthrospira): An Important Source of Nutritional and Medicinal Compounds. Journal of Marine Biology 2013: $1-8$.

Patterson GML, Baker KK, Baldwin CL, Bolis CM, Caplan FR, Larsen LK, Lavine IA, Moore RE, Nelson CS, Tschappat KD, Tuang GD, Boyd MR, Cardellina JH, Collins RP, Gustafson KR, Snader KM, Weisloi OS, Lewin RA (1993) Antiviral activity of cultured blue-green algae (Cyanophyta)1. Journal of Phycology 29: 125-130.

Rahman MM, Escobedo-Bonilla CM, Wille M, Alday Sanz V, Audoorn L, Neyts J, Pensaert MB, Sorgeloos P, Nauwynck HJ (2006) Clinical effect of cidofovir and a diet supplemented with Spirulina platensis in white spot syndrome virus (WSSV) infected specific pathogen-free Litopenaeus vannamei juveniles. Aquaculture 255: 600-605.

Ramakrishnan R (2013) Antiviral properties of cyanobacterium, Spirulina platensis-A review. International Journal of Medicine and Pharmaceutical Sciences (IJMPS) 3: 1-10.
Reboleira J, Freitas R, Pinteus S, Silva J, Alves C, Pedrosa R, Bernardino S (2019) Spirulina. In Nabavi SM, Silva AS (Ed). Nonvitamin and Nonmineral Nutritional Supplements, Elsevier.

Sharaf M, Amara A, Aboul-Enin A, Helmi S, Astani A, Schnitzler P (2010) Molecular authentication and characterization of the antiherpetic activity of the cyanobacterium Arthrospira fusiformis. Pharmazie 65: 132-136.

Shih SR, Tsai KN, Li YS, Chueh CC, Chan EC (2003) Inhibition of enterovirus 71-induced apoptosis by allophycocyanin isolated from a blue-green alga Spirulina platensis. Journal of Medical Virology 70: 119-125.

Singh S, Dwivedi V, Sanyal D, Dasgupta S (2020) Therapeutic and Nutritional Potential of Spirulina in Combating COVID-19 Infection (preprint).

Teas J, Hebert JR, Fitton JH, Zimba PV (2004) Algae - a poor man's HAART? Medical Hypotheses 62: 507-510.

Wan D, Wu Q, Kuča K (2016) Spirulina. In: Gupta RC (Ed). Nutraceuticals, Elsevier.

Woolhouse M, Scott F, Hudson Z, Howey R, Chase-Topping M (2012) Human viruses: discovery and emergence. Philosophical Transactions of the Royal Society B: Biological Sciences 367: 2864-2871.

Zainuddin EN, Mentel R, Wray V, Jansen R, Nimtz M, Lalk M, Mundt S (2007) Cyclic Depsipeptides, Ichthyopeptins A and B, from Microcystis ichthyoblabe. Journal of Natural Products 70: 1084-1088. 